\title{
EFFECTS OF DIGITALIZATON ON UKRAINIAN ECONOMY
}

\section{Iryna Sheiko ${ }^{1}$ \\ Oleksandra Storozhenko ${ }^{2}$}

DOI: https://doi.org/10.30525/978-9934-588-15-0-46

Abstract. The article deals with questions of digitazation of Ukrainian economy. The world has entered a new era in which the impact of digital technology is increasingly felt in all sectors of the economy. Digitalization is dramatically changing traditional industries and sectors. Cardinal changes are also taking place in those sectors that are considered basic for the Ukrainian industry - metallurgy, oil and gas, energy, agro-industrial complex, etc. The aim of the article is to determine the tendencies, perspectives and threats of Ukrainian economy digitalization process and effects of introduction of industry 4.0 elements in the reality of manufactury production. To achieve this purpose such tasks were solved. The main theoretical aspects about industry 4.0 were indicated. The central role of digitalization nin development of Ukrainian economy and social sectors was pointed out. The main concepts of industry 4.0 in current Ukrainian circumstances were described. It was found, that the development of the digital economy and society of Ukraine is a crucial factor for the success of not only all reforms, but also Ukrainian business on the world stage. Ukraine is an important player in the global digital market, but unfortunately, solely as an exporter of IT services and brains. The legal basis, finansial requerements and infrastructure readiness were examined. Such support was compared with programmes in EU that support digitalization. Such comparison shows the existance of gaps in legislation, in governance of digitalization process on state and industrial levels. The matrix of SWOTanalysis of the prospects for implementing the industry 4.0 in the reality of industry in Ukraine was created. The main strengthes in Ukrainian digitalization process lies in a field of quallified personnel and advanced educational and scientific basis, high-developed IT sector. Weakness - in poor infrastructure

\footnotetext{
${ }^{1}$ Associated Professor,

Kharkiv National University of Radioelectronics, Ukraine

${ }^{2}$ Associated Professor,

Kharkiv National University of Radioelectronics, Ukraine

(C) Iryna Sheiko, Oleksandra Storozhenko
} 
and low level of horizontal and vertical integration between firms. Thanks to the introduction of the digital economy, small and medium-sized businesses have became global. Ukrainian companies can integrate into international value added networks, some of them are already successfully implemented. This is a way to increase exports and produce more value added products.

\section{Introduction}

Three industrial revolutions have led to changes in the domain of manufacturing - mechanization through water and steam power, mass production in assembly lines, and automation using information technology. However, over the past years, industries together with researchers and policy makers worldwide have increasingly advocated an upcoming fourth industrial revolution.

Over the past few years the European Union has addressed the topic of Industry 4.0 with the slogan "Advanced Manufacturing". A taskforce established in 2013 presented a working document (European Commission 2014) [7] which was primarily concerned with the challenge of the shrinking portion of manufacturing in the GDP of the European Union. In this publication on industrial policy titled "For a Renaissance of European Industry" the Commission stressed that digital technologies such as cloud computing, big data, the new industrial internet, applications, smart factories, robotics and 3-D printing were necessary conditions when it came to increasing the productivity of European industry.

The aim of the article is to determine the tendencies, perspectives and threats of Ukrainian economy digitalization and effects of introduction of industry 4.0 elements in the reality of manufacture production.

To achieve this purpose some tasks have to be solved. They are:

- analysis of the role current state of digitalization in Ukraine;

-analysis of legal, infrastructure and financial support for digitalization in Ukraine and comparison with the digitalization programmes in EU countries;

- comparison of industrial digitalization programms in Ukraine and EU countries;

- investigation of perspectives and challengers of digitalization in Ukraine.

We use such methods, as synthesis and analysis, comparative analysis, time series analysis, SWOT-analysis.

At first the role of digitalization at Ukrainian business sector should be pointed out, then the existant legal, infrastructure and finansial support of digital 
development should be explained (in comparison of Ukraine with digitalization programmes in EU countries). Manufacturing digitalization process as the basis of industry 4.0 development also need detail investigating. And as final result, we propose SWOT-analysis of Ukrainian digitalization process.

\section{Role of digitalization in the development of Ukrainian business sector}

The world has entered a new era in which the impact of digital technology is increasingly felt in all sectors of the economy. Digitalization is dramatically changing traditional industries and sectors. There is a change in classic business models, analog processes and operations flow to the Internet, there is an opportunity to formulate personal offers for each individual client. Automation and robotization minimize the need for human resources, and rapidly increase efficiency and productivity. Cardinal changes are also taking place in those sectors that are considered basic for the Ukrainian industry metallurgy, oil and gas, energy, agro-industrial complex, etc.

According to the opinion of the Digital Agenda of Ukraine initiative experts [4], in order to reach $\$ 1$ trillion in GDP in 2030E, it will take the next 3-4 years to actively stimulate the penetration of technologies and innovations in the economy that could potentially show significant growth, namely: mechanical engineering; military-industrial complex; transport and logistics; agricultural sector; food and processing industry; woodworking; metallurgy.

Separate focus should be placed on the creation of industrial clusters with the presence of high-tech areas, such as: robotics; bioengineering; 3D printing; artificial intelligence with a focus on the global market [4].

It is through the technologicalisation of industries, the provision of business incentives for digitization and the parallel development of hightech areas, according to UIF, that the digital economy will potentially reach up to $65 \%$ of GDP in 2030 .

The development of the digital economy in Ukraine will enable [4]:

- Create the conditions for an 8-10x economy growth and for an 7-10\%growth of industrial production per year over the next 10 years;

- Increase productivity significantly (IMF estimates require productivity growth of $\$ 8$ trillion to reach $\$ 71,000$ per employee to reach GDP, equivalent to the current level of productivity in high-tech sectors such as Belgium, Denmark, Finland, Germany, Sweden); 
- additional attraction to the country of investment in the development of Industry 4.0 - both in manufacturing and in R\&D centers, incubators and technology companies;

- Make a technological leap for the Ukrainian economy;

- Significantly increase the competitiveness of the Ukrainian economy in global markets;

- Create new business models, new segments and sectors, opportunities to quickly, conveniently, cheaply develop, scale and capitalize on any business;

- Create new jobs, demand for new professions.

Also Digital Agenda of Ukraine initiative experts pointed out, that digitalization can brings such effects for Ukrainian business [4]:

- growth of high-tech segments up to $20 \%$ per year;

- increase of production capacity - up to $60 \%$;

- an increase in the number of orders executed on time - up to $95 \%$;

- reduction of stocks - up to $20 \%$;

- increase of efficiency of installed equipment - up to $15 \%$;

- reduction of equipment downtime - up to $22 \%$;

- savings in procurement costs - up to $30 \%$;

As for machine-building industry, due to digitalization production lines will reconfigure themselves automatically in order to optimise productivity. Some of that will be driven from above, with production lines responding dynamically to new or amended production orders, tying in seamlessly with logistics and the wider business. Some will be driven from the product itself, communicating with the line to determine the optimal route through the production process. For example, if there is a bottleneck at some point the production line, the product will recognize this and look to see if there are other processes that might be accomplished first, and instruct the line to reroute its progress [11].

\section{Legal, infrastructure and financial support for digitalization in Ukraine}

Digitalization process need legislative, infrastractural and finansial support. On January 17, 2018, the Cabinet of Ministers of Ukraine approved the Concept of Development of the Digital Economy and Society of Ukraine for 2018-2020. The main purpose of the Concept is to implement the 
accelerated scenario of digital development as the most relevant for Ukraine in terms of challenges, needs and opportunities [2].

The main goals of digital development are: accelerating economic growth and attracting investment; transformation of economic sectors into competitive and efficient ones; technological and digital modernization of industry and creation of high-tech industries; accessibility to citizens of the benefits and opportunities of the digital world; implementation of human resources, development of digital industries and digital entrepreneurship.

The integration of digital technologies in production processes is a priority of state industrial policy due to Concept. The state policy of stimulating the development of Industry 4.0 has three directions: creation of Infrastructure of Industry 4.0 - industrial parks, industry centers of technology; access to capital to create new innovative productions; development of digital skills for training personnel [2].

According to this state Concept, within the next three years (2018-2020), the government will modernize digital infrastructure, promote the development of Internet technologies and provide incentives for high-tech projects. The roadmap aims to cover 80 percent of the Ukrainian territory with broadband Internet by 2021 and carry out the digitalization of such sectors as education, medicine, ecology, infrastructure and transport [2].

Today, thanks to the digital economy, $22 \%$ of world GDP is created, for example in China $-30 \%$ of its GDP (\$3.4 trillion) [2]. According to the government's estimates, the planned digital economy development could increase the country's projected gross domestic product growth by 5 percent by 2021. Currently, about 35 percent of Ukraine's rural population has no access to the broadband Internet [2]. Digital economy sectors are growing faster, cheaper and better. Life spheres, such as education, medicine, and transport, which are being upgraded with the help of digital technologies, are becoming much more efficient and creating new value and quality.

In 2016 Association of IT and Association of Industrial automation created Industry 4.0 movement in Ukraine. Since then they tryed to understand the status of digitization by different sectors of industry and how they can accelerate this development. Survey about digitalization in mechanical engineering industry has passed for the first time. Actually, this is it the sector is a driving force for development of the whole industry in the era 4.0. After all, the basis of the intelligent productions are reasonable (smart) machines. 
But it is not the only reason why the focus today is on the machine building.

The dramatic decline in this sector after 2014 has called into question the very existence of the industry - to the extent and limits that have been more or less maintained since 1991. In addition to the traditional explanation of the loss of CIS markets, the development of exports to other markets and competition on the domestic market made the issue of competitiveness of Ukrainian Manufacturers to the top line. And among the factors of competitiveness, members of Associacions particular interest is in those directly affected by digitalization [1].

At Association of Industrial Automation of Ukraine (AIAU) the data of survey about digitalization of Ukrainian economy were represented [1]. The survey was attended by over 200 respondents, most of whom were representatives business structures: small, medium-sized and large industrial enterprises. Universities researches and lectures also took significant part. Respondents represent, in fact, the cut-off of the entire IoT life cycle and key stakeholders - vendors, system integration, industrial enterprises, IT companies, education and research segments. On the one hand, respondents are well-informed with industry trends 4.0, recognize our lag, but also believe in the significant impact of digital transformation on competitiveness of their enterprises in the future.

Two thirds of the respondents are already positioning themselves as Internet of Things (IoT) providers, and almost everyone plans to do so in the near future. And, at the same time, almost everyone thinks about the problem of cyber security IoT, up to the need for certification of devices.

Of course, there are problems and barriers. Innovators suffer from a lack of investors and insufficient linkages within local economic systems. These barriers are powered by the lack of competence in advanced technologies such as machine learning, artificial intelligence, information security; the solution of that can be found in cooperation and partnership.

Respondents defined that most important partners are financial and investment organizations, vendors of industrial automation, integrators and research centers. However, more than half of the respondents say that the partners are not ready for cooperation. Respondents hope for mutually beneficial cooperation, but there are barriers to communication: lack of formal structures or local associations. The ideology of IoT is a smart interaction, and the lack of such interaction is pointed out by majority of respondents [1]. 
Due to Digital agenda [4] and state Concept [2], total investments in digitalization of industry, business and manufacturing by 2030 can reach up to $\$ 70$ billion, and in digital infrastructure - up to $\$ 16$ billion. ( $80 \%$ of this come from private companies).

Despite of legislative initiatives expets point out low involvement of state institutions in the implementation of the Concept of Digital Economy and Society Development and mismatch between national, regional, sectoral strategies and digital development programs.

If we discuss support for digitalizing process, we need to discuss publicity and easy access to information (data). One of the most important values for the development of the digital economy is data. Access to public, professional, industrial and other data (government, municipal) is an important tool for the emergence of new products and services, which directly affects economic growth. According to Bughin studies [4], free circulation of data in EU countries can contribute to a cumulative growth of the EU economy by $0.5-1 \%$.

In 2015, a law on access to public information is in force in Ukraine, according to which public data of state bodies and enterprises should be accessible online. According to TAPAS, in 2017 the economy of Ukraine received over $\$ 700$ million through the use of opendata. The growth forecast is up to $\$ 1.4$ billion by 2025 . The state should play the role of both the data user and their key provider for the private sector. At present, the quality and volume of data provided by Ukrainian state institutions are insufficient, as evidenced by the Open Data Barometer, which ranks Ukraine $18^{\text {th }}$ among the 30 countries surveyed. In another, similar, ranking - Global Open Data Index - Ukraine gained 31st place out of 94.

As about infrastructure for digitalization, due to state Concept there are plans to implement solid infrastructure construction projects and create soft infrastructures - citizen ID, mobile ID, bank ID, open data, e-government, interoperability, e-commerce and e-business, transaction processing infrastructure, life-support infrastructure, geo-information infrastructure, blockchain infrastructure. But nowadays the main infrastructure problems of Ukraine are: Low level of coverage of the territory of the country with digital infrastructures (for example, the goal of the EU to cover $100 \%$ of the territory by broadband internet access by 2020, in Ukraine this figure is about $60 \%$ ), absence of separate digital infrastructures (for example, Internet of Things 
infrastructure, electronic identification and trust, etc.), Unequal access for citizens to digital technologies and new opportunities (digital gaps).

So, Ukraine have much to do to support digitalization on legislative, infrastructure and finansial aspects.

\section{Industrial digitalization on Industry 4.0 basis in Europe and Ukraine}

Digitalization of industry is a major component of the digital economy and a determining factor for the growth of the economy as a whole, including the digital industry itself, as a technology producer. Digital technology in many sectors is at the heart of product and manufacturing strategies. Their transformative power nowadays change traditional business models, manufacturing chains and processes, leading to the emergence of new products and services, platforms and innovations.

Industry 4.0 or Manufacturing IoT systems connect the components of a production process in a factory. Their purpose is to enable "smart manufacturing". In smart factories, cyber-physical systems monitor physical processes and make decentralized decisions. Via their IoT connection, these cyber-physical systems can communicate and cooperate with each other and with humans in real time. Connected devices include manufacturing equipment and robots [13].

The concept of i4.0 is based on linkage of virtual and physical parts of business processes along a supply chain. The virtualization is gained by Internet of Things (IoT), Internet of Services (IoS) and Internet of people (IoP). Virtualization of material and people by attached barcode or RFID tag, electronic devices and tools by new IPv6, integration of IT systems that currently insularly support supply chain processes can create CPS in which task can be simulated from product engineering to aftermarket services. There are 3 main pillars (technology, management, social aspect) that that have to be well established similarly in both a company and a country. I4.0 is not solely based on automation. It can go hand in hand with lean and help to achieve additional benefits where traditionally low investments measures of lean cannot enable further process performance improvements [11].

Over the past few years the European Union has addressed the topic of Industry 4.0 with the slogan "Advanced Manufacturing". A taskforce established in 2013 presented a working document (European Commission 
2014) [7] which was primarily concerned with the challenge of the shrinking portion of manufacturing in the GDP of the European Union. In this publication on industrial policy titled "For a Renaissance of European Industry" the Commission stressed that digital technologies such as cloud computing, big data, the new industrial internet, applications, smart factories, robotics and 3-D printing were necessary conditions when it came to increasing the productivity of European industry. The Commission defined three objectives [7]:

- faster commercialisation of advanced manufacturing technologies;

- reduction of demand shortfalls for advanced manufacturing technologies;

- promotion of skills for advanced manufacturing.

Likewise, in 2014 the new EU research programme Horizon 2020 was launched - by 2020 the Commission wants to earmark $€ 77$ billion of funding, including $€ 24.4$ billion for "research excellence" and $€ 17$ billion of funding for industrial innovations and so-called key technologies [8].

Furthermore, national and regional initiatives are to be connected and investments are to be supported through strategic partnerships and networks, which the European Commission hopes will alone generate around $€ 50$ billion in public and private investment in the digitalisation of industry: $€ 37$ billion investment in digital innovations; $€ 500$ million of European funds plus $€ 5$ billion of national and regional funding for so-called "Digital Innovation Hubs" (DIH); €6.3 billion for the first production lines of "Next-Generation Electronic Components"; $€ 6.7$ billion for the European Cloud Initiative.

The European manufacturing industry is responsible for $15 \%$ of GDP. Countries with an especially large manufacturing sector include Germany and Ireland, as well as various Eastern European countries. However, for a market to be promising for Industry 4.0 services it also needs to be ready for these techniques. This depends on, for example, production process maturity, degree of automation, degree of innovation, industry openness and internet use [8].

Industry 4.0 readiness is considerably greater in western and northern Europe than in other parts of European Union. As the founder of the movement, Germany scores particularly high. Combining readiness with the importance of the manufacturing sector reveals four types of European markets (table 1) [8]. 
Table 1

Classification of EU countries based on readiness to digitalization [8]

\begin{tabular}{|c|l|l|}
\hline Type & \multicolumn{1}{|c|}{ Readiness to digitalization } & \multicolumn{1}{c|}{ Countries } \\
\hline Frontrunners & $\begin{array}{l}\text { These countries generally have a large } \\
\text { manufacturing industry and modern, forward- } \\
\text { looking business conditions and technologies }\end{array}$ & $\begin{array}{l}\text { Germany, Ireland, } \\
\text { Sweden, Austria. }\end{array}$ \\
\hline Potentialists & $\begin{array}{l}\text { The manufacturing industries of these countries } \\
\text { are in decline. However, they possess a modern } \\
\text { and innovative outlook that gives them the } \\
\text { potential to implement Industry 4.0 techniques }\end{array}$ & $\begin{array}{l}\text { Belgium, Finland, } \\
\text { Netherlands, } \\
\text { Denmark, United } \\
\text { Kingdom, France. }\end{array}$ \\
\hline \multirow{5}{*}{ Traditionalists } & $\begin{array}{l}\text { These mainly Eastern European countries have } \\
\text { a thriving manufacturing industry, which could } \\
\text { make them promising Industry 4.0 markets. } \\
\text { However, so far these markets continue to } \\
\text { focus on traditional manufacturing and are not } \\
\text { ready for digitisation. }\end{array}$ & $\begin{array}{l}\text { Czech Republic, } \\
\text { Hungary, Slovakia, } \\
\text { Slovenia, Lithuania. }\end{array}$ \\
\hline Hesitators & $\begin{array}{l}\text { These countries do not have a particularly strong } \\
\text { manufacturing industry. In addition, the sector is } \\
\text { not ready for Industry 4.0 in these countries. }\end{array}$ & $\begin{array}{l}\text { Italy, Spain, Estonia, } \\
\text { Portugal, Poland, } \\
\text { Croatia, Bulgaria. }\end{array}$ \\
\hline
\end{tabular}

Even Eastern European countries appears mainly at zones of "Traditionalists" and "Hesitators", the experience of them will be useful for making clear the way Ukrainian economy should pass.

Průmysl 4.0 (Industry 4.0) is a national initiative aiming to maintain and enhance the competitiveness of the Czech Republic in the wake of the Fourth Industrial Revolution. The concept was firstly presented during the $57^{\text {th }}$ International Engineering Fair in Brno, September 2015 and approved by the Government of the Czech Republic on $24^{\text {th }}$ August 2016. The Ministry of Industry and Trade plays a key role in the implementation process, however, there is a strong interdisciplinary cooperation between the ministries, social and industrial partners and academia. The goal is to prepare not only the industry but the whole society for the economic and societal changes related to the fourth industrial revolution. P40 has a wide focus on the creation of business and social environment, in which the Czech economy can reach its full potential. At the same, the initiative aims to mobilize private sector, R\&D and industry associations, and academia to actively participate in the implementation process [6]. 
The Czech Republic has one of the highest shares of industrial production per GDP among EU countries (approximately 32\% GDP). Furthermore, the country has strong industrial ties to Germany, which is its strategic business partner. Czech companies mainly supply industrial components to its neighboring country, thus integrating into the German industrial supply chain.

The national innovation fund ( $€ 1.87$ million) brings together financial resources from the European Structural and Investment Funds, OP PIK and additional $€ 1.2$ million from the private sector and it is considered as a possible source of a refundable form of financial support, of which part would be reinvested in the new projects. Further programs Trio ( $€ 140$ million), Gama and Epsilon administrated by the MPO are considered as other options of the funding for the realization of the P40 activities. These programs aim to improve knowledge transfer between the industry and R\&D institutions. At this stage, no model for private financing is in place. The Government is planning to explore different possibilities [6].

The main goal is to create an appropriate business and social environment with the main focus on building the data and communication infrastructure, adaptation of education system, introducing new labour market instruments and creating financial policy supporting companies with investment in the new technologies and know-how. At this stage, there is no more specific information available.

As about Poland, The Future Industry Platform was announced as part of the Responsible Development Plan ('Morawiecki Plan') by the Ministry of Finance and Development in 2016 [15]. Providing industrial financing over a 25-year period, the Morawiecki Plan pursues an agenda of reindustrialisation through new partnerships, export oriented support measures and comprehensive regional development. The main mission of the Platform will be to act as an integrator of all stakeholders interested in Industry 4.0 as well as an accelerator of the digital transformation of Polish industry. The Platform seeks to achieve these goals through a mix of activities comprising knowledge transfer and awareness raising, as well as the development and application of digital transformation support measures. With a total planned investment of $€ 235$ billion over the next 25 years, the Plan seeks to unleash the potential of the economy to achieve development that improves the quality of life in Poland.

At Lithuania the National Industry Digitisation Platform 'Pramone 4.0' was established and country became the first Baltic State that has such 
platform [14]. The platform unites all the major stakeholders from different sectors and is the main consensus building instrument in Lithuanian ecosystem for industry digitalization. Taking into account the benefits to be received of implementation of such initiative and the meaning for Lithuanian future economy, the Minister of Economy of the Republic of Lithuania supported such initiative and take the role to steer and coordinate the Platform. The platform seeks competitiveness and the productivity of industry as well as on promoting industry in the integration of digital solutions and new technologies. The platform serves as a venue for active and early stage involvement of major stakeholders (including businesses) at various levels (Commission 'Pramonè 4.0 ', Coordination group, thematic working groups), thus helping to create a strong dialogue between industry, research, education and governmental institutions to anticipate change, adapt to the future needs, propose the most efficient solutions for the digitalisation of industry. The platform has highlevel representation from policy makers and from industry leaders.

As about reality of Ukrainian enterprises, our country has a strong positions at manufacturing industry, which could make them promising Industry 4.0 markets. However, these industries continue to focus on traditional manufacturing and are not ready for digitalisation. As of 2019, Ukraine is a country with a degrading industry, low regulatory efficiency, weak internal demand for technology (including Industry 4.0 technology), and a strong IT industry, as well as a rather powerful (compared to emerging markets) university educational system [3].

Integration of digital technologies into production processes, or the digitization of industry, is a priority of state industrial policy. Due to Concept of development of the digital economy and society of Ukraine for 2018-2020 [2] the state policy of stimulating the development of Industry 4.0 has three directions:

- creation of infrastructure of Industry 4.0 - industrial parks, industry centers of technology, etc.;

- access to capital to create new innovative industries;

- developing digital skills to train staff capable of working with Industry 4.0 technologies.

A case of successful digitalization of domestic machine-building enterprise is represented by state enterprise "FED" (Kharkiv) [3]. FED is one of the leading companies engaged in production of components for 
aircraft engines and control systems for civil aviation purposes (actuators, power systems, components for high-lift control systems). The main users of their products on Ukrainian market are JSC "Motor Sich" designer bureau «Progress», Kharkov aviation plant, Enterprises SE "Antonov" and other Ukrainian enterprises. The company extensively cooperates with companies from Ukraine, belarus, China, Czech Republic and Canada [3].

With the goal of entering foreign markets, the company focused its business strategy on quality, innovation and export. Managing these factors, as well as timing and price, was impossible without technological modernization, modern information technologies and automation. Therefore, in 2011, the company launched a large-scale project on the implementation of an automated system for planning, accounting and analysis of Enterprise Resource Planning (ERP) business processes. And in 2013, FED launched a new project for the implementation of information technologies from IT-Enterprise-SmartFactory [3]. Digital transformation of the business using the elements of Industry 4.0 helped the enterprise to increase the capacity of the equipment and improve delivery time.

Then such modulas were introduced: SmartFactory Production Management Modules (APS / MES, MRPII), PDM / PLM (design and technological preparation of production, archive of design and technological documentation), material inventory management, tool management, procurement management, controlling (scheduling and the actual cost price of the finished product), SmartManager (electronic document management of the enterprise). All these phases ensures integrated production management. In addition, IT-Enterprise modules for accounting and tax accounting, as well as personnel management and salary calculation were introduced.

The first results of implementation were obtained during the year. Stability and reliability in terms management already then allowed the enterprise to guarantee the fulfillment of new orders from the world's leading aircraft manufacturers in the amount of more than hundreds of millions of dollars. The results of implementation at the end of 2017 are as follows:

1. The functionality of the system is implemented in full. As the main result, instead of the planned increase in throughput up to $10 \%$, it increased to $15 \%$. Production cycles at the same time reduced by an average of $25 \%$.

2 . The number of people involved in coordination tasks has decreased. For example, the dispatch service, previously engaged in planning tasks, 
was reduced from 10 to 2 people, while the amount of planning tasks increased several times.

3. Significantly increased the efficiency and productivity of all staff. The system eliminated unproductive losses of time and errors for various tasks of manual planning, coordination, coordination, preparation of production and decision making at various levels. In general, the production planning process was reduced from a few days to a few minutes.

4. Annual sales growth of $30-70 \%$ pushes growth of salary, while maintaining high labor productivity.

To receive more such histories of success, road transformation maps are a must-have element for the rapid digitization of individual businesses and industries. Until our businesses and industries begin to build such development maps and provide them with appropriate plans and budgets, the digitalization movement will remain chaotic, and consequently, with numerous errors and losses, and consequently at a slow speed. But in order for businesses to prepare such cards faster, the country needs to train industry experts and consultants to build such maps. Best practices already tested in other developed countries should be quickly tested and replicated in Ukraine.

\section{Perspectives and challengers of digitalization in Ukraine}

Digitalization creates new sectors and segments, as well as new professions. According to the Ukrainian Institute of the Future, up to $60 \%$ of value added in Ukraine in $2030 \mathrm{E}$ will be created in new high-tech sectors of the economy, such as artificial intelligence, robotics, bioengineering, 3D printing, nanomedicine and others. In the future, $65 \%$ of our children will engage in activities that do not yet exist today.

Based on previous studies $[5 ; 9 ; 10 ; 11 ; 13 ; 16 ; 17]$, there is broad consensus that digital technologies can yield positive effects on productivity at the firm and industry level. However, productivity gains from digital adoption are not automatic. They depend crucially on firms' organisational capital and management skills, as well as on their ability to deploy complementary investments and innovations to improve business processes and automate certain routine tasks. In addition, productivity gains can take time to materialise.

The digital economy is not a separate sector of GDP, such as the ICT industry or industry, it is a platform that permeates all sectors of the 
economy, dramatically changes them, changes the very structure of the Ukrainian economy, creates new segments and even industries.

The impact of digitalisation is determined by the added value it creates for each sector of economy or sector at the macroeconomic level, or for a particular product or service at the micro level. The main effect of digitization is the change in value chains. Technology and digitization will drive people out of their usual processes - manufacturing, service, entertainment, commerce, education and even medicine. In this case, the return on investment (ROI) will dramatically increase in business. Digital Spillover estimates that the digital ROI is 6.7 times higher than traditional.

According to research in the Digital Spillover report, every dollar invested in digital technology leads to a GDP growth of $\$ 20$, ie an investment multiplier of 20. For comparison, the traditional (non-digital) multiplier is 2-8 (depending on industry).

Ukraine lacks a model for calculating the economic impact of information and communication technologies (ICTs) on certain industries and sectors of life. The current digital statistics system only applies to the amount of equipment imported into the country and the volume of exports of IT companies services. There is also no official data on the coverage of the territory of the country by digital infrastructures and the level of consumption of such services.

However, let us consider only the aggregate volume of ICT equipment and services consumed in Ukraine in 2018 - it is approximately $\$ 1.560$ billion. (estimated by International Data Corporation). For example, Poland's economy consumed \$ 6.5 billion in IT products in 2018 .

This means that the economy of Ukraine is underfunded in terms of its consumption of ICT, that is, the pace and scale of modernization of the economic and life spheres is much lower than that of its countires-neighbors. Overall, the level of consumption of ICT products and services leads to a conclusion about the level of modernization of the country and the level of its productivity and efficiency, and therefore its competitiveness.

According to Digital agenda of Ukraine [4] the main effects of digitalization for economy will be such (table 2).

Analysis of experts' and researchers' opinion $[1 ; 2 ; 3 ; 4 ; 11]$ give us the basis for creating SWOT-matrix of digitalization of Ukrainian economy (table 3). 
Main effects of digitalization of Ukraine [4]

\begin{tabular}{|c|c|c|c|c|}
\hline Index & 2021 & 2025 & 2030 & $\begin{array}{c}\text { Total } \\
\mathbf{2 0 2 1 - 2 0 3 0} \\
\end{array}$ \\
\hline Investing in digital infrastructure & $\$ 0,7$ bill. & $\$ 3$ bill. & \$6 bill. & $\$ 16$ bill. \\
\hline $\begin{array}{l}\text { Investments in digitalization of } \\
\text { production, business, industry }\end{array}$ & $\$ 1,5$ bill. & $\$ 5$ bill. & $\begin{array}{l}\$ 14 \\
\text { bill. }\end{array}$ & $\$ 70$ bill. \\
\hline $\begin{array}{l}\text { Increase in productivity through } \\
\text { digitization }\end{array}$ & $+1,1 \%$ & $+13 \%$ & $+13 \%$ & \\
\hline $\begin{array}{l}\text { GDP additionally generated through } \\
\text { digitization (only the effect of investment } \\
\text { and productivity gains) }\end{array}$ & $\$ 17$ bill. & $\begin{array}{l}\$ 93 \\
\text { bill. }\end{array}$ & $\begin{array}{l}\$ 280 \\
\text { bill. }\end{array}$ & $\$ 1260$ bill. \\
\hline - additional GDP in $\%$ & $+11 \%$ & $+44 \%$ & $+95 \%$ & \\
\hline Additional revenue to the Budget & $\$ 3,2$ bill. & $\begin{array}{l}\$ 17 \\
\text { bill. }\end{array}$ & $\begin{array}{l}\$ 50 \\
\text { bill. }\end{array}$ & $\$ 240$ bill. \\
\hline $\begin{array}{l}\text { Number of jobs created (excluding } \\
\text { the export IT industry), persons }\end{array}$ & 150000 & $\begin{array}{l}300 \\
000 \\
\end{array}$ & 700000 & \\
\hline $\begin{array}{l}\text { Digital economy share in Ukraine } \\
\text { (in total GDP) }\end{array}$ & $3 \%$ & $15 \%$ & $65 \%$ & \\
\hline
\end{tabular}

Ukraine has all the conditions to make the so-called digital leap and move to a higher technological level of development, namely:

- ability to produce and use information-communication and digital technologies, availability of professional staff. This is evidenced by statistics of real successes of Ukrainian IT companies in international markets;

- access to relevant equipment, technology, dissemination of technology to citizens and businesses. This is evidenced by the gradual renewal of internal demand for technology, market "success stories" in various spheres of life and economy, the availability of local representations of technology manufacturers, distribution of high-tech equipment;

- sufficient level of system integration of technological products and services - from design to complex implementations of various technologies, software and hardware;

- creative culture and the ability to generate ideas, as evidenced by high scores in the Global Innovation Index.

High developed traditional sectors can be a good basis for providing elements of digitalization. For Ukraine, machine building is one of the most priority andexport oriented industries, where it already has world 


\section{SWOT-matrix of digitalization of Ukrainian industry}

\begin{tabular}{|c|c|}
\hline \begin{tabular}{l}
\multicolumn{1}{c}{ STRENGTH } \\
High developed IT sector \\
High level of personnel education \\
Scientific Potential of R\&D centres and \\
Universities \\
Powerfull basis of traditional sectors of \\
manufacturing \\
Suitable logistic for Ukrainian firms
\end{tabular} & $\begin{array}{l}\text { WEAKNESS } \\
\text { Lack of vertical and horizontal integration } \\
\text { Poor infrastructure } \\
\text { Low salaries and expected work shortage } \\
\text { The lack of private investments } \\
\text { Consentration of finansial resources at } \\
\text { traditional sectors } \\
\text { Digitalization is not a top prioriti for } \\
\text { Ukrainian top managers } \\
\text { Low productivity }\end{array}$ \\
\hline $\begin{array}{l}\quad \text { OPPORTUNITIES } \\
\text { Reducing trade barriers } \\
\text { Increasing of high-tech export } \\
\text { Reducing production costs } \\
\text { Reducing errors in planning } \\
\text { Reducinig costs of inventory } \\
\text { Creating a more flexible research and } \\
\text { educational system in line with laboure } \\
\text { market needs }\end{array}$ & \begin{tabular}{l}
\multicolumn{1}{c}{ THREATS } \\
Regres in traditional sectors of economics \\
Top-management resistance for changes \\
Increasing of competition on Ukrainian \\
market \\
Data cybersecurity problems \\
Standartization and cyber security is not \\
in line with global standards.
\end{tabular} \\
\hline
\end{tabular}

recognition. At the same time, our enterprises are critically in need of modernization and construction of modern digital models in management. Therefore, the sooner the machine-building enterprises will understand the importance of the development and implementation of: enterpise resource planning systems, supply chain management systems, production process control systems (APS / MES-systems) and other enterprise management systems, the sooner Ukraine will take a step towards a strong industry.

Strategy 4.0 argues why there are no conditions for any positioning among the leaders in the next 5 years - the leading 20-30 post-industrial states of the world. Instead, Ukraine can be at least a regional leader in complex and high-tech engineering services, such as:

- Programming in the field of industrial high-tech / creation of new software products, including new technologies 4.0;

- design (electrical, mechanical, electronic, technological, construction, etc.);

- industrial automation and integrated engineering (including commissioning of industrial sites);

- development and production of complex, small-scale or unique products. 


\section{Conclusions}

In Ukrainian perspective there is a large-scale digitalization of all branches of the economy and basic spheres of life, strengthening of investments in infrastructure development, innovations and modern technologies. After all, digital technology reduces barriers to entering new markets, allows you to automate a huge amount of mechanical work, upgrade equipment, optimize management processes. An important aspect: thanks to the introduction of the digital economy, small and medium-sized businesses have became global. Ukrainian companies can integrate into international value added networks, some of them are already successfully implemented. This is a way to increase exports and produce more value added products [13].

The development of the digital economy and society of Ukraine is a crucial factor for the success of not only all reforms, but also Ukrainian business on the world stage. Ukraine is an important player in the global digital market, but unfortunately, solely as an exporter of IT services and brains.

For the domestic market, Industry 4.0 should be a catalyst for the growth of the industry as well as the defense-industrial complex. A huge challenge for Industry 4.0 in the internal market is the involvement in the digitalisation of the Ukrainian industry and energy in the IT sector, as well as in science. Currently, both categories fall out of these processes. The vision by 2030 includes and consolidates this positioning: Ukraine is a high-tech, post-industrial country integrated into global value chains that produce unique engineering services and high quality products. Ukraine is self-sufficient in providing its economy and the army with the most necessary technological products.

\section{References:}

1. Association of Industrial Automation of Ukraine (AIAU) (2018). Industrija 4.0 v mashynobuduvanni: stan v Ukrajini ta perspektyvy rozvytku. Analitychnyj zvit [Industry 4.0 in Mechanical Engineering: Situation in Ukraine and Prospects for Development. Analytical report]. URL: https://industry4-0-ukraine.com.ua/ 2018/10/18/analitychnyj-zvit-industrija-4-0-v-mashyno/

2. Cabinet Ministers of Ukraine. Order from 17 January 2018 r. № 67-p «Pro skhvalennja Koncepciji rozvytku cyfrovoji ekonomiky ta suspiljstva Ukrajiny na 2018-2020 roky ta zatverdzhennja planu zakhodiv shhodo jiji realizaciji» [On Approval of the Concept of Development of the Digital Economy and Society of Ukraine for 2018-2020 and Approval of the Plan of Measures for its Implementation].

3. Association of Industrial Automation of Ukraine (AIAU) (2018). Cystema upravlenyja proyzvodstvom na predpryjatyy FED [Production management system at the FED Enterprise], IT-Enterprise.SmartFactory. URL: https://industry4-0ukraine.com.ua/smart-factory/ 
4. HITECH Office (2016). Cyfrova adzhenda Ukrajiny - 2020 ("Cyfrovyj porjadok dennyj” - 2020). Konceptualjni zasady (versija 1.0). Pershocherghovi sfery, iniciatyvy, proekty "cyfrovizaciji" Ukrajiny do 2020 roku [Digital Agenda of Ukraine - 2020 ("Digital Agenda" - 2020). Conceptual backgrounds (version 1.0). Priority areas, initiatives, projects for "digitization" of Ukraine until 2020], HITECH Office. URL: https://ucci.org.ua/uploads/files/58e78ee3c3922.pdf

5. Andrews, D., G. Nicoletti and C. Timiliotis (2018). "Digital technology diffusion: A matter of capabilities, incentives or both?", OECD Economics Department Working Papers, No. 1476, OECD Publishing, Paris. doi: http://dx.doi.org/10.1787/7c542c16-en

6. Czech Republic: "Průmysl 4.0" Digital Transformation Monitor. May, 17. URL: https://ec.europa.eu/growth/tools-databases/dem/monitor/sites/default/files/ DTM_Prumys1\%2040_CZ\%20v1.pdf

7. European Commission 2014c: "Advancing Manufacturing - Advancing Europe": Report of the Task Force on Advanced Manufacturing for Clean Production, Commission Staff Working Document, SWD (2014) 120 final, Brussels.

8.. Industry 4.0 in Europe. CBI. Ministry of Foreign Affairs. URL: https://www.cbi.eu/market-information/outsourcing-itobpo/industry-40/

9. Lopez-Gonzalez, J. and J. Ferencz (2018). "Digital trade and market openness", OECD Trade Policy Papers, No. 217, OECD Publishing, Paris. doi: http://dx.doi.org/10.1787/1bd89c9a-en

10. López González, J. and M. Jouanjean (2017-07-27). "Digital Trade: Developing a Framework for Analysis", OECD Trade Policy Papers, No. 205, OECD Publishing, Paris. doi: http://dx.doi.org/10.1787/524c8c83-en

11. McKinsey Industry 4.0 How to navigate digitization of the manufacturing sector. McKinsey Digital. 2015. URL: https://www.mckinsey.com/ /media/ McKinsey/Business\%20Functions/Operations/Our\%20Insights/Industry\%2040\%20 How $\% 20$ to $\% 20$ navigate $\% 20$ digitization $\% 20$ of $\% 20$ the $\% 20$ manufacturing $\% 20$ sector/Industry-40-How-to-navigate-digitization-of-the-manufacturing-sector.ashx

12. OECD (2019). "Trade in the Digital Era", OECD Going Digital Policy Note, OECD, Paris. URL: www.oecd.org/going-digital/trade-in-the-digitalera.pdf

13. OECD (2019a). Measuring the Digital Transformation: A Roadmap for the Future, OECD Publishing, Paris. doi: https://doi.org/10.1787/9789264311992-en

14. Platform Pramonè 4.0 Structure. URL: https://industrie40.lt/platformpramone-4-0-structure/

15. Poland: Initiative for Polish Industry 4.0 - The Future Industry Platform. Digital Transformation Monitor. February, 2018. URL: https://ec.europa.eu/growth/ tools-databases/dem/monitor/sites/default/files/DTM_Poland\%20_vf.pdf

16. Sorbe, S., et al. (2019). "Digital Dividend: Policies to Harness the Productivity Potential of Digital Technologies", OECD Economic Policy Papers, No. 26, OECD Publishing, Paris. doi: https://doi.org/10.1787/273176bc-en

17. Sorbe, S., P. Gal and V. Millot (2018). "Can productivity still grow in service-based economies? Preliminary evidence and scoping for further research", OECD Economics Department Working Papers, No. 1531, OECD, Paris. 